\title{
SKAUSMAS IR DISKOMFORTAS ORTODONTINIO GYDYMO BREKETŲ SISTEMA METU
}

\author{
Gustė Markevičiūtè1, Vilija Berlin ${ }^{1,2}$ \\ ${ }^{1}$ Vilniaus universiteto Medicinos fakulteto Odontologijos institutas, \\ ${ }^{2}$ Vilniaus universiteto ligoninès Žalgirio klinika
}

Raktažodžiai: skausmas ir diskomfortas, ortodontinis gydymas, breketų sistema, skausmo valdymo strategijos.

\section{Santrauka \\ Skausmas ir diskomfortas yra dažni nepageidaujami, tačiau laikini ortodontinio gydymo reiškiniai. Tyrimu duomenimis, ortodontinio gydymo metu skausmą patiria 72-100 proc. pacientų. Be skausmo, pacientai gali jausti kitus nemalonius pojūčius burnoje ar socialinị diskom- fortą. Skausmas ir diskomfortas yra subjektyvūs pojūčiai, priklausantys ir nuo paciento psichosocialinių aplinkybių. Skausmas dažniausiai prasideda praejjus kelioms valan- doms po breketų užklijavimo ir būna intensyviausias po 24 valandų. Skausmo pojūtis mažèja 3-7 dieną, kol visiškai stabilizuojasi, praejjus mènesiui. Ortodontinis skausmas (diskomfortas) dažniausiai nedidelis ir trunka neilgai. Kai kuriems pacientams skausmas būna intensy- vesnis, gali trukdyti kasdienei veiklai, tačiau dažniausiai - tik gydymo pradžioje. Ortodontinis skausmas turi už- degiminių savybių, todèl net ir didejant susidomejjimui nefarmakologinèmis skausmo valdymo strategijomis, efektyviausiai ortodontinis skausmas malšinamas tik vartojant vaistus nuo skausmo. \\ Šiame straipsnyje apžvelgiama ortodontinio skausmo etiologija, skausmo ir diskomforto priklausomybė nuo paciento individualių savybių, nemalonių pojūčių ịtaka gyvenimo kokybei bei skausmo valdymo strategijos.}

\section{Ivadas}

Skausmas apibūdinamas kaip nemalonus fizinis ir emocinis pojūtis, kylantis dèl galimo arba esamo audinių pažeidimo [1]. Diskomfortas gali būti apibūdinamas kaip nemalonus pojūtis, kuris ortodontinio gydymo metu pasireiškia burnos ertmès suvaržymu, minkštụjų audinių tempimu, gleivinès spaudimu, liežuvio padèties pasikeitimu ar dantų maudimu [2]. Skausmo ir diskomforto suvokimas yra subjektyvus ir gali priklausyti nuo psichosocialinių aplinkybių ar individualių paciento savybių, amžiaus, lyties, emocinès būklès ir skausmo slenksčio, todèl šiuos pojūčius sunku ištirti $[1,3]$. Skausmas yra viena iš ortodontinio gydymo baimių ir viena pagrindinių priežasčių, dèl kurių pacientai linkę mažiau bendradarbiauti su gydytoju, atidèlioti vizitus arba nutraukti gydymą $[4,5]$.

Skausmą ortodontinio gydymo metu patiria apie 72-100 proc. pacientų [6]. Šis skausmas yra periodonto spaudimo, išemijos, uždegimo ir edemos rezultatas [1,7]. Ortodontinis dantų judejjimas sukelia uždegimines periodonto bei danties pulpos reakcijas, skatinančias ịvairių biocheminių mediatorių, sukeliančių skausmą, išsiskyrimą. Ortodontinio gydymo metu stebimi kraujotakos pokyčiai - padidèja kraujyje cirkuliuojančių leukotrienų, prostaglandinų, citokinų, bradikininų, P substancijos, histamino, dopamino ir serotonino kiekis. Veikiant ortodontinems jègoms, šie mediatoriai lemia hiperalgezinị periodonto atsaką $[1,4]$. Ortodontinès jẻgos aktyvuoja juntamuosius periodonto audinių receptorius, kuriais skausminis impulsas toliau plinta tiek periferine, tiek centrine nervų sistema [6].

Tyrimo tikslas - apžvelgti mokslinès literatūros duomenis apie skausmą ir diskomfortą, patiriamą ortodontinio gydymo breketų sistema metu, ir aptarti farmakologinius bei nefarmakologinius skausmo valdymo būdus. Tyrimo uždaviniai: 1) nustatyti ortodontinio gydymo breketų sistema sukelto skausmo ir diskomforto intensyvumą; 2) išsiaiškinti, ar skausmo ir diskomforto intensyvumas gali priklausyti nuo individualių paciento savybių; 3) aptarti skausmo ir diskomforto įtaką pacientų gyvenimo kokybei; 4) pristatyti farmakologinius ir nefarmakologinius ortodontinio skausmo valdymo metodus.

\section{Tyrimo medžiaga ir metodai}

Tyrimo metodas - mokslinès literatūros, nagrinèjančios skausmo ir diskomforto pasireiškimą bei malšinimą ortodontinio gydymo breketų sistema metu, apžvalga. Tyrimo šaltiniai: moksliniai straipsniai, elektroninès mokslinių straipsnių duomenų bazès. 


\section{Tyrimo rezultatai}

Vaizdo analogijos skalės panaudojimas skausmo ir diskomforto vertinimui. Skausmas ir diskomfortas yra subjektyvūs pojūčiai, todèl juos sunku standartizuoti ir įvertinti. Pastebèta, kad veikiant panašaus dydžio ortodontinèms jẻgoms, pacientų skausmo vertinimai stipriai varijuoja [7]. Skausmo suvokimui daro ịtaką pacientų psichologinè būsena bei ekonominiai, socialiniai ir aplinkos veiksniai. Nepaisant to, daugelis tyrèjų, norėdami geriau suprasti pacientų patirti taikant skirtingus gydymo metodus, remiasi būtent skausmo ir diskomforto rodikliais.

Šiems pojūčiams ištirti buvo sukurta vaizdo analogijos skalè (VAS). Tai horizontali linijine $10 \mathrm{~cm}$ skalè, kurioje pacientų prašoma pažymèti skausmo (diskomforto) intensyvumą nuo 0 (nèra skausmo/diskomforto) iki 10 (didžiausias įmanomas skausmas/diskomfortas) [8].

Skausmo ir diskomforto pasireiškimas ortodontinio gydymo breketais metu. Remiantis įvairių tyrimų duomenimis, skausmas prasideda praejjus vos kelioms valandoms po breketų užklijavimo ir būna intensyviausias praejus 24 valandoms nuo ortodontinių jẻgų veikimo pradžios [6-8]. Skausmo pojūtis mažèja 3-7 dieną, kol visiškai stabilizuojasi praejjus mėnesiui [6]. Dažniausiai skausmą ir diskomfortą sukeliančios ortodontinès procedūros: separacinių gumyčiu uždèjimas, breketų vielos aktyvacija, mini implantų įsriegimas ir breketų nuemimas [1]. Nustatyta, kad fiksuoti ortodontiniai aparatai sukelia didesnị skausmą nei išimamieji [9].

Literatūroje nurodoma, kad uždèjus separacines gumytes, pacientai pradeda jausti skausmą ir diskomfortą po 4 valandų. Nemalonūs pojūčai intensyvèja 24 val. ir visiškai praeina per 7 dienas [4]. M. Jawaid ir bendraautorių tyrimo duomenimis, skausmas praejjus 24 val. po separatorių uždèjimo vidutiniškai sieke 5,9 VAS balus. Pacientai, kurių dantų susigrūdimas buvo didesnio laipsnio, jaute didesnị skausmą po separatoriaus uždejjimo, kadangi esant labai glaudiems interproksimaliniams dantų kontaktams, dedant separacines gumytes buvo naudojama didesnè spaudimo jèga [5].

Uždèjus breketų lanką, skausmas dažniausiai pasireiškia praejjus 4 val. ir būna didžiausias po 24 valandų. Kai kuriems pacientams šis skausmas gali būti didesnis, nei po dantų šalinimo [4]. M. Jawaid ir kitų atliktame tyrime skausmas praejjus 24 val. po breketų užklijavimo vidutiniškai siekè 6,26 balus [5]

Skirtingos breketų sistemos gali sukelti skirtingo intensyvumo nemalonius pojūčius. N. Sahoo ir kiti lygino metalinių ir keraminių breketų sukeltą skausmą skirtingose dantų lanko srityse ir nustate, kad skausmo balai buvo aukščiausi, praejus 24 val. po breketų užklijavimo tiek metalinių, tiek keraminių breketu grupejje. Skausmas palaipsniui sumažèjo per 5 dienas. Tyrèjai pastebejjo, kad pacientai, kuriems buvo užklijuoti keraminiai breketai, skundèsi didesniu skausmu - manoma, kad tai galëjo lemti keramikos sukuriama didesnè trintis. Tyrejjai nustatè, kad praejjus 24 val. po breketų užklijavimo, didžiausias skausmas buvo jaučiamas viršutinio žandikaulio priekinių dantų srityje ( 4,4 balai keraminių breketų grupejje ir 2,7 balai metalinių breketu grupejje), o mažiausias - apatinio žandikaulio šoninių dantų srityje $(0,78$ balai keraminių breketų grupeje ir 0 balų metalinių breketų grupeje) [3]. Netolygus skausmo pasiskirstymas tarp dantu grupių buvo pastebètas ir A. Erdniç kartu su bendraautoriais atliktame tyrime, kuriame skausmo pojūtis priekinių dantų srityje buvo didesnis nei šoninių dantų srityje, tačiau skirtumai nebuvo statistiškai reikšmingi [7]. Manoma, kad didesnis skausmas priekinių dantų srityje jaučiamas dèl to, kad jų šaknų paviršiaus plotas yra mažesnis, jie daugiau įtraukti ị tiesinimą bei yra naudojami kandimui [4].

Lyginant tradicinius breketus (OPA-K, gamintojas Japonijos bendrovė Tomy) su neligatūriniais (Damon Q, gamintojas JAV įmonė Ormco), statistiškai reikšmingų skirtumų tarp skausmo pojūčiu nenustatyta, nors Damon Q gamintojų teigimu, neligatūriniai breketai sukuria mažesnę trintị ir mažesne jèga išjudina dantis, todèl pacientai turètų jausti mažesnį skausmą. Abiejų sistemų grupėse skausmas pasireiške praèjus 4 val. po breketų uždèjimo, buvo intensyviausias praejjus 24 val., pradejo mažèti po 3 dienų ir po savaitès išnyko [8].

Breketų nuėmimo procedūra taip pat gali būti nemaloni pacientams. Diskomforto pojūtis šios procedūros metu priklauso nuo dviejų pagrindinių dalykų: danties paslankumo ir jëgos tipo. Periodonto struktūrų išsidėstymas leidžia atsispirti intruzinėms kramtymo jëgoms, todèl intruzinès jẻgos panaudojimas nuimant breketus sukelia mažiau skausmo, lyginant su mezialinėmis, distalinėmis, facialinėmis, lingvalinèmis ar ekstruzinèmis jègomis $[4,10]$. Gydytojai ortodontai, norèdami sumažinti diskomfortą breketų nuemimo metu, turètų stabilizuoti dantis pirštu arba paprašyti paciento sukąsti vatos voleli [10].

Kadangi skausmo suvokimas yra subjektyvus, vieniems pacientams procedūra gali būti nemaloni, o kitiems ta pati procedūra tokia skausminga, jog jie galiausiai atsisako gydymo. Dẻl skausmo slenksčio individualumo sunku nuspèti, kaip pacientas priims tam tikrą gydymą, tačiau yra dalykų, kuriuos gydytojas gali kontroliuoti ir kiek įmanoma sumažinti nemalonių potyrių pasireiškimą. Visų pirma, siūloma rinktis minimalią ortodontinę jègą, kuri sukurs optimalų dantų judejjimą. Antra, reikia užtikrinti, kad naudojami ortodontiniai aparatai nesudirgintų minkštųų audinių - breketų dydis turi būti parinktas individualiai pacientui pagal jo dantų dydi, breketo kraštai užapvalinti ir gerai nupoliruoti, breketu viela pritaikyta pagal paciento 
dantų lanko kontūrą, o jos kraštai užlenkti. Jei įmanoma, rekomenduojama rinktis elastines ligatūras vietoje metalinių, nes jos yra mažiau dirglios [11].

Skausmo ir diskomforto priklausomybė nuo psichosocialinių paciento savybių. Skausmo suvokimas gali priklausyti nuo paciento lyties, amžiaus, motyvacijos ir požiūrio ị gydymą, nuo buvusio gydymo patirties ar emocinès būklès, tačiau šiuos veiksnius sunku ištirti, todèl ịvairiu tyrimų rezultatai yra skirtingi [4, 5, 12-14].

Tradiciškai manoma, kad moterys gležnesnès ir jautresnès, o vyrai stipresni, todèl jaučia mažesnį skausmą, tačiau ịvairių tyrimų rezultatai prieštaringi [4]. Pavyzdžiui, L. Campos ir kitų atliktame tyrime reikšmingai didesni skausmą jautè moterys nei vyrai [12]. M. Jawaid ir bendraautoriu tyrime vyrai jaute statistiškai reikšmingai daugiau skausmo nei moterys [5]. Skausmo priklausomybè nuo amžiaus taip pat vertinama prieštaringai, tačiau literatūroje yra duomenų, kad ortodontinio gydymo metu jaunesni pacientai dažnai jaučia didesni skausmą nei vyresnieji. Jauname amžiuje, ypač paauglystëje, vyksta intensyvus psichologinis vystymasis, kurio metu jaučiamos sustiprejjusios emocijos, o kartu ir stipresnis skausmas. Be to, šiuo gyvenimo laikotarpiu pacientai dažniausiai dar nèra išlavinę skausmo valdymo strategiju [12]. Vis dèlto, amžiaus įtaką skausmo suvokimui siūloma vertinti atsargiai, kadangi skirtingo amžiaus pacientams taikomos skirtingos gydymo metodikos [4].

Literatūroje pabrezžiama sklandžios gydytojo ir paciento komunikacijos svarba. Informacijos apie galimą diskomfortą stoka gali tapti viena pagrindinių prasto bendradarbiavimo priežasčių [4]. J. Singh ir bendraautorių tyrime dalyvavę pacientai, kurie jautėsi informuoti ir įtraukti i gydymo planavimą, jautè mažesni skausmą. Pastebèta, kad skambinimas telefonu pacientams ir domejjimasis jų būkle taip pat turèjo įtakos skausmo sumažèjimui [13]. S. Banerjee ir kiti nustate, kad pacientai, kurie suprato ortodontinio gydymo svarbą, jaute mažesnio intensyvumo diskomfortą, o nepakankamas paciento informuotumas bei paciento ir gydytojo komunikacijos stoka buvo pagrindinès priežastys, dèl kurių pacientas nutraukè ortodontini gydymą [14].

Dar diagnostinès fazès metu svarbu įvertinti paciento požiūrị i gydymą [4]. L. Campos ir kitų tyrime pacientai, kurie patys sieké ortodontinio gydymo ir buvo patenkinti rezultatais, skundèsi reikšmingai mažesniu skausmu [12]. A. Kavaliauskienè ir kiti, atlikę tyrimą Lietuvoje, nustatè, kad motyvuoti pacientai jautè mažiau skausmo ir diskomforto ortodontinio gydymo metu tiek fiksuotais, tiek funkciniais ar išimamais aparatais [2]. Pastebèta, kad motyvacija ortodontiniam gydymui, ypač jaunesniojo amžiaus vaikų, dažnai yra maža. Nustatyta, kad tèvai dažniausiai turèjo didesnę motyvaciją nei jų vaikai, kuriems reikejo ortodontinio gydymo [14].
Šiais laikais vis daugiau suaugusiujų siekia ortodontinio gydymo, o tai reiškia, kad gydytojai ortodontai vis dažniau susiduria su pacientais, kurie kenčia nuo pastovaus streso, nerimo ar depresijos [11]. Paciento emocinè būklè daro reikšmingą ịtaką skausmo ir diskomforto pasireiškimui, o skausmo pojūtis dažniausiai tiesiogiai nepriklauso nuo ortodontinių jègų dydžio, bet labiau siejasi su paciento psichologine gerove [4].

Skausmo ir diskomforto įtaka pacientų gyvenimo kokybei. Ortodontinis skausmas ir diskomfortas dažniausiai nedidelis ir trunka neilgai, tačiau kai kurių pacientų skausmas būna toks intensyvus, jog kartais gali būti prilyginamas vapsvos ịgèlimui ar čiurnos išnirimui $[2,14]$. Didžiausias ortodontinis skausmas pasireiškia gydymo pradžioje, kai dantys turi pajudèti didesniu atstumu [11], todèl skausmo itaka pacientų gyvenimo kokybei dažniausiai stebima ankstyvose gydymo stadijose. Laikui bègant ortodontinis skausmas mažèja ir stabilizuojasi, pacientai pripranta prie ortodontinio aparato, todèl diskomforto nebejaučia [14]. Be skausmo ir diskomforto ortodontinio gydymo metu gali būti jaučiamas nepasitikèjimas savimi dèl netenkinančios breketų išvaizdos, nepriimtinos šypsenos estetikos ar kalbos sutrikimo [2]. Beveik visi pacientai, kuriems taikomas ortodontinis gydymas, patiria tam tikro lygio kramtymo sunkumų, todèl daugelis turi keisti savo mitybos ịpročius ir rinktis minkštesnị maistą [4].

L. Baidas ir bendraautoriu atlikto tyrimo duomenys parodè, kad pirmają breketų užklijavimo dieną daugeliui tiriamujų skaudèjo burną ( 86,8 proc.), kiti jautė diskomfortą valgymo metu (76,3 proc.), negalejo valgyti ịvairių maisto produktu (63,2 proc.), buvo sunku atsipalaiduoti (47,4 proc.), jautėsi ịsitempę ir susigėdę (42,1 proc.), kai kuriems pacientams sumažèjo pasitikèjimas savimi (36,8 proc.) [15]. Daugiau nei pusè A. Erdniç ir kitų tyrimo dalyvių skundèsi negalintys sportuoti ar dalyvauti socialiniuose susibūrimuose praejjus 6 val. po breketų užklijavimo, tačiau praejjus kelioms dienoms, nusiskundimų skaičius sumažèjo [7]. S. Banerjee ir kitų tyrime 85 proc. pacientų nurodè suprastejusią gyvenimo kokybę po fiksuoto ortodontinio aparato uždejjimo. Silpnas skausmas ir diskomfortas buvo jaučiamas dantų valymosi metu, stiprus skausmas ir diskomfortas - kramtymo metu [14]. S. Paes da Silva ir bendraautorių tyrimo rezultatai atskleidè, kad pacientų, gydomų fiksuotais ortodontiniais aparatais, skirtingai nei išimamaisiais, su burnos sveikata susijusi gyvenimo kokybė buvo prastesnè. Fiksuoti ortodontiniai aparatai galèjo kelti nepatogumų dèl minkštujų audinių traumavimo ar pasunkejusios higienos. Šiame tyrime dar buvo nagrinejjami skirtingo amžiaus ortodontiškai gydomų pacientų dažniausi nusiskundimai: 6-11 metų vaikai nurodè pasunkẻjusį žodžių tarimą ir diskomfortą valgymo 
metu, paaugliai (12-17 m.) - diskomfortą valgymo metu ir skausmą burnoje, suaugusieji pacientai (>18 m.) - diskomfortą valgymo metu, padidejjusią emocinę įtampą ir sumažèjusį pasitikèjimą savimi. Visi pacientai mažiausiai skundèsi blogu skoniu burnoje ir negalejimu dirbti dèl ortodontinio gydymo [16].

Farmakologiniai skausmo valdymo būdai. Dantų judejjimą sukelia nuolat veikiančios mechaninès jègos, kurias sukuria ortodontiniai prietaisai. Šio proceso metu, kaip minèta anksčiau, vyksta uždegiminiai pokyčiai periodonto audiniuose, kraujyje padaugeja uždegiminių mediatorių, sukeliančių skausmą [17], todèl skausmo kontrolè ortodontinio gydymo metu (ypač gydymo pradžioje) yra labai svarbi.

Farmakologiniam skausmo valdymui dažniausiai naudojami nesteroidiniai vaistai nuo uždegimo (NVNU), pavyzdžiui, ibuprofenas, aspirinas ar naproksenas. Šie preparatai veikia kaip prostaglandinų inhibitoriai, todèl mažina sisteminị uždegiminị procesą. Prostaglandinai dalyvauja kaulo rezorbcijoje, todèl jų slopinimas gali neigiamai paveikti dantų judèjimo greitị ar sukelti dantų šaknų rezorbciją $[14,17]$. Jei pacientas sveikas, analgetikai pašalinami iš organizmo dar prieš prasidedant dantų judejimui, todèl gydymo pradžioje NVNU pavartojus trumpą laiką ir mažomis dozèmis, dantų judejjimo greitis nebus paveikiamas $[4,18]$.

Kitas populiarus vaistas nuo skausmo yra paracetamolis (dar žinomas kaip acetaminofenas), kurio pirminis veikimo mechanizmas panašus ị NVNU, tačiau paracetamolis daugiau veikia centrinę nervų sistemą ir neinhibuoja prostaglandinų, todèl neturi neigiamo poveikio dantų judejimui. Acetaminofenas neturi priešuždegiminio poveikio, tad siūloma ji vartoti kartu su NVNU [9]. C. Cheng ir bendraautorių metaanalizèje nurodoma, kad norint pasiekti optimalią skausmo kontrolę po separacinių gumyčių ar breketų lanko uždèjimo, rekomenduojama vartoti $400 \mathrm{mg}$ ibuprofeno ir $600 \mathrm{mg}$ paracetamolio 1 val. prieš procedūrą arba praèjus 6 val. po procedūros [18].

Nèra bendros nuomonès, kurie preparatai veiksmingiausi ortodontinio skausmo kontrolei. Lyginant NVNU ir paracetamolio skausmo malšinimo efektyvumą, daugelyje tyrimų statistiškai reikšmingų šių preparatų skirtumų nenustatyta [19]. Lyginant ibuprofeno ir paracetamolio skausmo mažinimo poveikị praejus 2 val., 6 val. ir 24 val. po separatorių uždẻjimo ir pradinio dantų tiesinimo, statistiškai reikšmingų skirtumų nerasta [9].

Nefarmakologiniai skausmo valdymo būdai. Literatūroje aprašomas skausmo malšinimas nefarmakologiniais metodais, tačiau jų efektyvumas vertinamas prieštaringai. Ganètinai plačiai nagrinèjamas becukrès kramtomosios gumos poveikis skausmui malšinti. Šis nefarmakologinis skausmo valdymo būdas grindžiamas tuo, kad kramtant gumą dantys laikinai išjudinami, todèl atsiranda pakankamai vietos kraujui pritekèti ị spaudimo zonas ir neleisti ten kauptis metaboliniams produktams. Ritminis kramtymo procesas šiek tiek slopina nociceptinius receptorius [4]. Nenustatyta, kad kramtomoji guma yra efektyvesnè už vaistus nuo skausmo, tačiau yra duomenų, kad jos kramtymas gali sumažinti analgetikų vartojimo dažnį $[20,21]$. Daugelis gydytojų nerekomenduoja kramtyti gumos esant uždètiems breketams, nors nenustatyta, kad gumos kramtymas gali padidinti breketų atsiklijavimo riziką [21, 22].

Literatūroje nagrinejjami ir alternatyvūs skausmo malšinimo būdai. Tai vibracinè stimuliacija bei žemo lygio lazerio terapija (angl. low-level laser therapy, LLLT). Vibracinès stimuliacijos panaudojimą ortodontinio skausmo malšinimui 2003 metais pirmą kartą apraše S. Marie su bendraautoriais. Pacientams, kurie iki tol jaute diskomfortą, vibracija buvo itin nemaloni, todèl tyrèjai rekomenduoja ši būdą nebent kaip prevencinę priemonę prieš pasireiškiant skausmui [23]. Vis daugiau tyrejų domisi žemo lygio lazerio terapija, kadangi ji pasižymi analgetiniu poveikiu, padeda regeneruoti audinius ir gali paskatinti dantu judèjimą [21]. S. Aljudaibi metaanalizèje rašoma, kad pritaikius LLLT, pacientų skausmas praèjus 24 val. po fiksuoto aparato uždejjimo sumažèjo 2,02 VAS balais, tačiau kol kas trūksta įrodymų pagrịsti šios terapijos efektyvumą [24].

Paciento psichologinè būklè gali iškreipti skausmo suvokimą, todèl manoma, kad elgesio terapija gali mažinti ortodontinio gydymo skausmo pojūtị [22]. Tyrimų duomenimis, profesionali sisteminė akupunktūra, atlikta prieš ortodontini gydymą, gali sumažinti skausmą tiek moterims, tiek vyrams, todèl ji taip pat laikoma saugiu skausmo kontrolès metodu [21].

Kol kas nèra pakankamai ịrodymų, kad nefarmakologiniai skausmo malšinimo metodai yra efektyvūs ortodontinio skausmo malšinimui [24], todél manoma, kad efektyvi skausmo kontrolè gali būti pasiekta tik derinant nefarmakologinius skausmo valdymo būdus su vaistais nuo skausmo [19].

\section{Išvados}

1. Skausmas ir diskomfortas yra didžiausias praėjus 24 val. nuo breketų užklijavimo, tačiau šie pojūčiai trunka neilgai ir ženkliai sumažèja per savaitę, o visiškai stabilizuojasi praèjus mènesiui.

2. Skausmas ir diskomfortas labiausiai priklauso ne nuo paciento amžiaus ar lyties, bet nuo jo emocinès būklès, informuotumo ir motyvacijos.

3. Skausmas ir diskomfortas daugiausia ịtakos pacientu gyvenimo kokybei turi gydymo pradžioje. Pacientai dažniausiai skundžiasi pasunkejjusiu kramtymu ir pasikeitusiais 
valgymo ịpročiais, vèliau prisitaiko prie ortodontinio aparato ir gyvena ịprastinį gyvenimą.

4. Kai reikia malšinti skausmą ortodontinio gydymo breketais metu, efektyviausia vartoti vaistus nuo skausmo arba analgetikus derinti su nefarmakologiniais skausmo malšinimo būdais.

\section{Literatūra}

1. Almuzian M, Rizk MZ, Ulhaq A, Alharbi F, Alomari S, Mohammed H. Effectiveness of different debonding techniques and adjunctive methods on pain and discomfort perception during debonding fixed orthodontic appliances: a systematic review. Eur J Orthod 2019;41(5):486-494.

https://doi.org/10.1093/ejo/cjz013

2. Kavaliauskiene A, Smailiene D, Buskiene I, Keriene D. Pain and discomfort perpection among patients undergoing orthodontic treatment: results from one month follow-up study. Stomatologija 2012;14(4):118-125.

3. Sahoo N. Comparison of the perception of pain during fixed orthodontic treatment with metal and ceramic brackets. J Pharm Bioallied Sci 2019;11(Suppl 1):S30-S35. https://doi.org/10.4103/JPBS.JPBS_218_18

4. Krishnan V. Orthodontic pain: from causes to management--a review. Eur J Orthod 2007;29(2):170-9. https://doi.org/10.1093/ejo/cj1081

5. Jawaid M, Qadeer TA, Fahim MF. Pain perception of orthodontic treatment - A cross-sectional study. Pak J Med Sci 2020;36(2):160-165. https://doi.org/10.12669/pjms.36.2.619

6. Long H, Wang Y, Jian F, Liao LN, Yang X, Lai WL. Current advances in orthodontic pain. Int J Oral Sci 2016;8(2):67-75 https://doi.org/10.1038/ijos.2016.24

7. Erdinç AM, Dinçer B. Perception of pain during orthodontic treatment with fixed appliances. Eur J Orthod 2004;26(1):79-85. https://doi.org/10.1093/ejo/26.1.79

8. Lai TT, Chiou JY, Lai TC, Chen T, Wang HY, Li CH, Chen $\mathrm{MH}$. Perceived pain for orthodontic patients with conventional brackets or self-ligating brackets over 1 month period: a single-center, randomized controlled clinical trial. J Formos Med Assoc 2020;119(1 Pt 2):282-289.

https://doi.org/10.1016/j.jfma.2019.05.014

9. Monk AB, Harrison JE, Worthington HV, Teague A. Pharmacological interventions for pain relief during orthodontic treatment. Cochrane Database Syst Rev 2017;11(11):CD003976. https://doi.org/10.1002/14651858.CD003976.pub2

10. Kilinç DD, Sayar G. Evaluation of pain perception during orthodontic debonding of metallic brackets with four different techniques. J Appl Oral Sci 2019;27:e20180003. https://doi.org/10.1590/1678-7757-2018-0003

11. Legris S. Managing pain and discomfort in orthodontics. Journal of Dentofacial Anomalies and Orthodontics 2011;14(1), 109. https://doi.org/10.1051/odfen/2011108

12. Campos LA, Santos-Pinto A, Marôco J, Campos JADB. Pain perception in orthodontic patients: a model considering psychosocial and behavioural aspects. Orthod Craniofac Res 2019;22(3):213-221.

https://doi.org/10.1111/ocr.12315

13. Singh J, Dixit P, Singh P, Kedia NB, Tiwari MK, Kumar A. Pain perception and personality trait toward orthodontic treatment. J Int Soc Prev Community Dent 2017;7(6):377-380. https://doi.org/10.4103/jispcd.JISPCD_419_17

14. Banerjee S, Banerjee R, Shenoy U, Agarkar S, Bhattacharya S. Effect of orthodontic pain on quality of life of patients undergoing orthodontic treatment. Indian J Dent Res 2018;29(1):4-9. https://doi.org/10.4103/ijdr.IJDR_113_16

15. Baidas LF, AlJunaydil N, Demyati M, Sheryei RA. Fixed orthodontic appliance impact on oral health-related quality of life during initial stages of treatment. Niger J Clin Pract 2020;23(9):1207-1214.

https://doi.org/10.4103/njcp.njcp_681_19

16. Paes da Silva S, Pitchika V, Baumert U, Wehrbein H, Schwestka-Polly R, Drescher D, Kühnisch J, Wichelhaus A. Oral health-related quality of life in orthodontics: a cross-sectional multicentre study on patients in orthodontic treatment. Eur J Orthod 2020;42(3):270-280.

https://doi.org/10.1093/ejo/cjz064

17. Corrêa AS, Almeida VL, Lopes BMV, Franco A, Matos FR, Quintans-Júnior LJ, Rode SM, Paranhos LR. The influence of non-steroidal anti-inflammatory drugs and paracetamol used for pain control of orthodontic tooth movement: a systematic review. An Acad Bras Cienc 2017;89(4):2851-2863.

https://doi.org/10.1590/0001-3765201720160865

18. Cheng C, Xie T, Wang J. The efficacy of analgesics in controlling orthodontic pain: a systematic review and meta-analysis. BMC Oral Health 2020;20(1):259. https://doi.org/10.1186/s12903-020-01245-w

19. Topolski F, Moro A, Correr GM, Schimim SC. Optimal management of orthodontic pain. J Pain Res 2018;11:589-598. https://doi.org/10.2147/JPR.S127945

20. Fleming PS, Strydom H, Katsaros C, MacDonald L, Curatolo M, Fudalej P, Pandis N. Non-pharmacological interventions for alleviating pain during orthodontic treatment. Cochrane Database Syst Rev 2016;12(12):CD010263. https://doi.org/10.1002/14651858.CD010263.pub2

21. Hussain AS, Al Toubity MJ, Elias WY. Methodologies in orthodontic pain management: a review. Open Dent J 2017;11:492-497. https://doi.org/10.2174/1874210601711010492

22. Alshammari AK, Huggare J. Pain relief after orthodontic archwire installation-a comparison between intervention with paracetamol and chewing gum: a randomized controlled trial. Eur J Orthod 2019;41(5):478-485. https://doi.org/10.1093/ejo/cjy081 
23. Marie SS, Powers M, Sheridan JJ. Vibratory stimulation as a method of reducing pain after orthodontic appliance adjustment. J Clin Orthod 2003;37(4):205-8; quiz 203-4.

24. Aljudaibi S, Duane B. Non-pharmacological pain relief during orthodontic treatment. Evid Based Dent 2018;19(2):48-49.

https://doi.org/10.1038/sj.ebd.6401305

\section{PAIN AND DISCOMFORT DURING ORTHODONTIC TREATMENT WITH BRACKETS}

\section{G. Markevičiūtè, V. Berlin}

Keywords: pain and discomfort, orthodontic treatment, brackets, pain management strategies.

Summary

Pain and discomfort are common but temporary side effects during orthodontic treatment.According to research, 72-100 proc. of orthodontic patients experience pain. Besides pain, patients may experience other unpleasant feelings in the mouth or social discomfort. Pain and discomfort are subjective sensations that can depend on the patient's psychosocial circumstances. Pain usually begins a few hours after the braces are applied and is most intense after 24 hours. The sensation of pain decreases in 3-7 days until it fully stabilizes after a month. Orthodontic pain / discomfort are usually mild and short-lasting. In some patients pain is more intense and may interfere with daily activities, but this usually occurs only at the beginning of treatment. Orthodontic pain has inflammatory properties, so even with increasing interest in non-pharmacological pain management strategies, the most effective orthodontic pain relief is only possible with the use of analgesics.

This article reviews the etiology of orthodontic pain, the dependence of pain and discomfort on individual patient characteristics, the influence of unpleasant sensations on patients' quality of life and pain management strategies.

Correspondence to: gustemark@gmail.com

Gauta 2021-02-15

\section{KVIEČIAME PRENUMERUOTI „SVEIKATOS MOKSLŲ“ ŽURNALĄ 2021 METAIS!}

Žurnalas „Sveikatos mokslai“ (Index Copernicus, EBSCO host (Academic Search Complete), Gale (Academic OneFile), ProQuest (Ulrich's, Summon), Australia (ERA) 2012 Journal List (ERA ID 34962) skirtas visų specialybių gydytojams, slaugytojams ir kitiems specialistams, spausdina mokslinius straipsnius lietuvių, anglų kalbomis. Reikalavimai straipsniams atitinka mokslo leidiniams keliamus reikalavimus. Žurnalas kioskuose neparduodamas. Žurnalą, kuris leidžiamas kartą per du mènesius, galima užsiprenumeruoti visuose Lietuvos pašto skyriuose, taip pat internetu: www.prenumeruok.It

Prenumeratos kaina nesikeičia: visiems metams - 36 EUR, šešiems mėnesiams - 18 EUR, keturiems mẻnesiams - 12 EUR, dviem mėnesiams - 6 EUR. Prenumeratos kodas: 5348.

Žurnalo autoriams straipsnių spausdinimas ir jų internetinè sklaida mokama. 